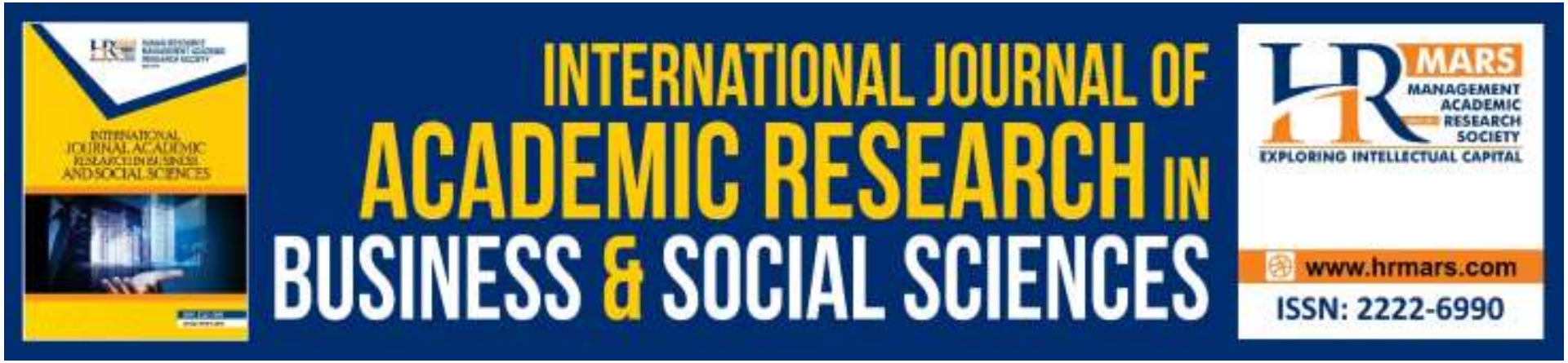

\title{
Factors Influencing Competitive Pricing for Airlines in Malaysia
}

Suhairah Abdul Mutalib, Zaiful Hasmi Hashim, Beni Widarman Yus Kelana, Ilham Sentosa, Rafidah Othman, Theresa C.F. Ho, Poh-Chuin Teo

To Link this Article: http://dx.doi.org/10.6007/IJARBSS/v10-i4/7110 DOI:10.6007/IJARBSS/v10-i4/7110

Received: 07 February 2020, Revised: 02 March 2020, Accepted: 26 March 2020

Published Online: 13 April 2020

In-Text Citation: (Mutalib et al., 2020)

To Cite this Article: Mutalib, S. A., Hashim, Z. H., Kelana, B. W. Y., Sentosa, I., Othman, R., Ho, T. C. F., \& Teo, P.-C. (2020). Factors Influencing Competitive Pricing for Airlines in Malaysia. International Journal of Academic Research in Business and Social Sciences, 10(4), 97-109.

Copyright: (C) 2020 The Author(s)

Published by Human Resource Management Academic Research Society (www.hrmars.com) This article is published under the Creative Commons Attribution (CC BY 4.0) license. Anyone may reproduce, distribute, translate and create derivative works of this article (for both commercial and non-commercial purposes), subject to full attribution to the original publication and authors. The full terms of this license may be seen at: http://creativecommons.org/licences/by/4.0/legalcode

Vol. 10, No. 4, 2020, Pg. 97 - 109

http://hrmars.com/index.php/pages/detail/IJARBSS

JOURNAL HOMEPAGE

Full Terms \& Conditions of access and use can be found at http://hrmars.com/index.php/pages/detail/publication-ethics 


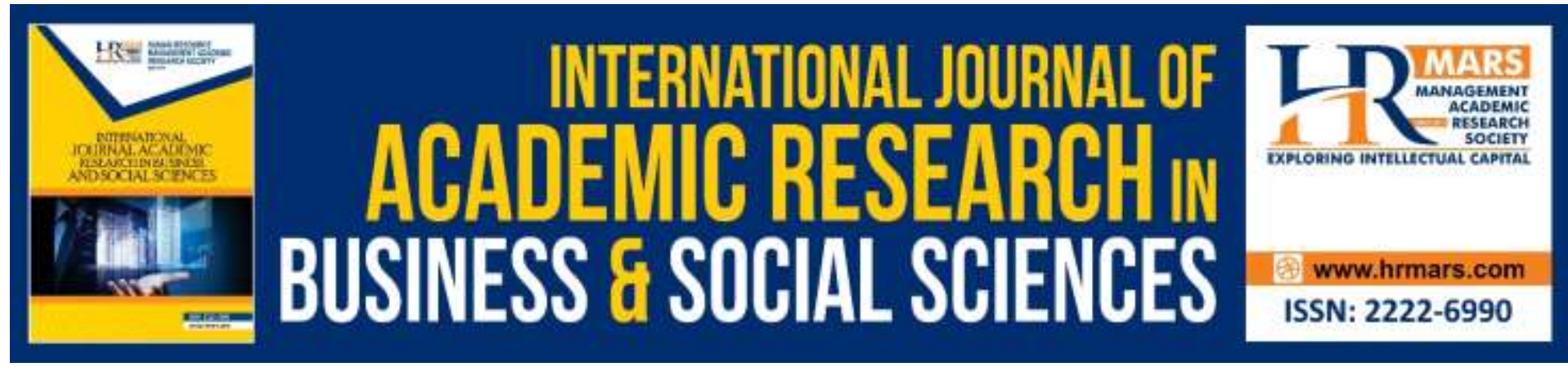

\title{
Factors Influencing Competitive Pricing for Airlines in Malaysia
}

\author{
aSuhairah Abdul Mutalib, aZaiful Hasmi Hashim, äBeni \\ Widarman Yus Kelana, 'llham Sentosa, aRafidah Othman, \\ aTheresa C.F. Ho, aPoh-Chuin Teo \\ ${ }^{a}$ Azman Hashim International Business School (AHIBS), Universiti, Teknologi Malaysia, \\ Malaysia

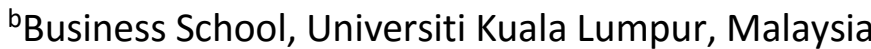

\begin{abstract}
The purpose of this study is to determine the factors that influenced competitive pricing for airlines in Malaysia. A particular route, Kuala Lumpur to Singapore has been selected as the case study whilst observing a comparison of competitive pricing between full service and low cost carriers. This research was derived in response of World's Busiest International Air Routes report from OAG Aviation Worldwide that shows more than 30,000 flights frequency on average in both directions for international route Kuala Lumpur to Singapore on an annual basis. This study will try to explore the influence in competitive pricing between forecast on demand and product quality. A framework model has been proposed to determine the factors on competitive airlines pricing in Malaysia. The outcome of this study is to assist airlines to develop an effective approach for competitive pricing for passengers to choose their desired air carrier for short haul flight sectors.
\end{abstract}

Keywords: Competitive Pricing, Forecast on Demand, Product Quality, Low Cost Carriers, Full Service Carriers.

\section{Introduction}

This study will determine the factors affecting airlines passenger's competitive pricing in purchasing airlines ticket between full service carriers (FSC) and low cost carriers (LCC) whilst focusing on one point of sales (POS) from the one of the busiest routing globally, Kuala Lumpur to Singapore. Kuala Lumpur International Airport (KLIA) has been ranked by The OAG International Megahubs Index 2019 as number 12th in its Top 20 most connected airports worldwide while Singapore Changi Airport (SIN) ranks 8th overall, is the largest Megahubs in Asia Pacific are all located in South East Asia. The key in measuring the effectiveness on this ranking is the comparison between leading international airports hubs as connecting points, globally and regionally. There is a research review of Kuala Lumpur International Airport (KLIA) due to its strategic location in the Centre of South East Asia famous airport, Singapore Changi International Airport (SIN), Bangkok Suvarnabhumi International Airport (BKK) and Jakarta Soekarno-Hatta International Airport (CGK)(Bardai et. al, 2017). The top three places for the low-cost International Megahubs remain as they were in 2017, with Kuala Lumpur Airport 
(KUL) ranked in 1st place. Low-cost carrier AirAsia dominates the airport with 40 percent of flight operations. - Ranked 2nd is Jakarta Airport (CGK) and in 3rd place is Singapore Changi Airport (SIN). At both airports the dominant airline is a legacy carrier indicating the strength of competition between prime legacy and low-cost budget airlines (The Megahubs International Index). This is one of the cause factor of war pricing competitiveness between the Full Service Network Carrier (prime carrier) and Low Cost Carrier (budget carrier) in airlines industry in Malaysia as stated by O'Connell and Williams (2005), low cost airlines have intensified the direct competition with full service airlines, particularly during the weak economic situation in 2008 and 2009. Today's air transport is a demanding and competitive business, where margins are tight and is usual that some airlines record losses of millions (Cento, 2008).

A uniqueness in the aviation industry is that this industry's capabilities captures the attention of the wide consumer because of its glamorous and ability to impact on the large and growing numbers of consumers worldwide (Chan, 2000). From the report determine by OAG Aviation, which shows that air routes between Kuala Lumpur and Singapore are the busiest routes in the world with 30,537 trips between the two airports in the year to February 2018. This is means that average of 84 flights per day plied in this route. Kuala Lumpur to Singapore overtook the previous dominated Asian destination route, Hong Kong to Taipei (Air Travel Industry Reports. OAG). For the operating carrier, there are two different key players in this route. A host of low cost carriers such as budget airlines Scoot, Jetstar, Air Asia and hybrid airlines, Malindo Air to compete with the two countries' flagship carriers, Malaysia Airlines and Singapore Airlines. This airlines legacy also known as Full Service Network Carrier or prime carrier.

This research is conducted to fill the research gap by studying factors of competitive dynamic pricing in Malaysia between routing KUL-SIN by understanding the pricing competitive in fare structure and design benchmarking approach between forecast on demand, product quality and market segmentation in bellows criteria's:

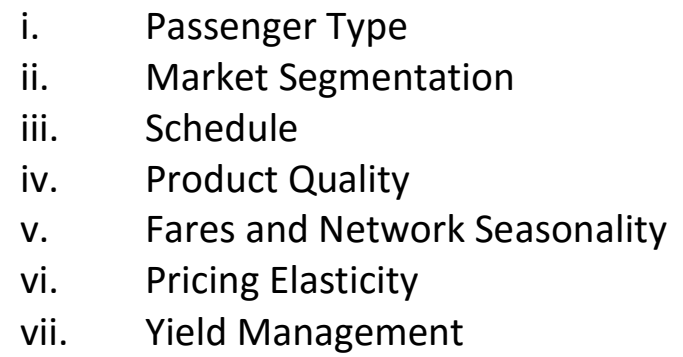

Looking into airline revenue management, an action in pricing setting and managing yield through inventory to optimize total revenue while inventory is just one input to the final price presented to a customer. To realize the potential of total revenue management, airlines must adopt a bundled model that considers not only ticket price but also the probability that passengers will purchase other products and services from the airline before, during, and after their journey.

The ability to make this important analysis is not an advantage to most airlines. Not everybody as some airline personnel are able to identify the concepts of ticket purchase to the airfare 
for passengers. There is a different control on pricing to be specific on the price range, seasonality, travel month and the significant seat capacity allotment that need to be analyze before the airlines distribute the fares to the trade. Price is the most important reason why passengers chose LCCs as compares to FSCs. This is considered to be one of the strengths of LCC over FSC airlines.

Robust demand for international air travel is making the pricing offers by competitor's airlines very sensitive and too competitive while flying between Kuala Lumpur and Singapore which only takes about an hour compare to driving that almost four hours in more than $296.7 \mathrm{~km}$ via North-South Expressway (NSE)/E2 (Google Maps). Some of the travelers will choose to fly instead of driving due to the distance and time. There is a research study about customer satisfaction is the most important contributor to customer loyalty (Oliver, 1999) and also has significant effect on the shareholder value (Anderson et.al, 2004). The emergence of LCCs managed to "steal" customers from the commercial airlines especially price sensitive customer. Even those high end customers are no longer willing to pay such a high fares on air transport and benefit the LCCs. Air transport is not a luxurious thing anymore. At this point of time, traditional airlines faced challenges from low cost airlines where they find difficulty on sustaining their business.

Therefore, to get an access on reviewing the best offer, airlines passenger will often use travel booking sites for price comparisons before the actual purchase via Computer Reservations System (CRS). A computer reservation system is used for the reservations of a particular airline and interfaces with a global distribution system (GDS) which supports travel agencies and other distribution channels in making reservations for most major airlines in a single system. Airline industry observers have generally assumed that the demand for airline travel is price elastic as per research regarding price discrimination involves selling different units of output at different prices. Indeed, one of the primary benefits expected with airline deregulation was a fall in the fare level and increased passenger traffic were regulatory real time price and service restrictions removed. Pricing in the airline industry is known to be very complex, resulting in substantial and well-documented price dispersion (Gerardi and Shapiro, 2009). Deneckere and Peck (2012) point out that airline industry belongs to a rather wide class of markets, in which good is offered for sale for a limited length of time, capacity is set in advance, and aggregate demand is uncertain. The phenomenon of the world growth in lowcost airlines has resulted in putting their focus on pricing strategies, issues of cost recovery and their impact on the traffic and market shares of legacy carriers or other low-cost carriers when they are competing, either directly or at adjacent airports.

The main objective of the research is,

- to study what is the most dominant factors that determined the influenced of the competitor strength specific for KUL-SIN route only.

Few study factors were found from literature like; Dynamic Airline Pricing and Seat Availability by Kevin R. Williams (2017) which show that the forces are complements in airline markets and lead to significantly higher revenues, as well as increased consumer surplus, compared to a more restrictive pricing regime as per Botimer (1996) and Belobaba and Wilson (1997) investigate effects of yield management external to the firm using it. Botimer (1996) presents arguments for efficiency of yield management pricing in the airline industry, and Belobaba and Wilson (1997) investigate the impacts of yield management introduction in competitive 
airline markets. Most yield management research is to deal with revenue maximization. One approach is to assume that customers arrive to request a flight, state the price they will pay, and then the firm decides whether or not to serve them. Van Slyke and Young (2000) study this situation in terms of filling a knapsack of fixed capacity with objects of known weights (or vector weights, to fill multi- dimensional knapsacks) and value, each type which arrives as a time-dependent Poisson process. With the goal of maximizing value, each object is accepted or rejected at the time of arrival. The case of equal weights is applied to airline seat inventory control, since each customer uses one seat, and the multi-dimensional knapsack is applied to the problem of allocating seats in a multiple origin and destination flight network. Customers arrive throughout the continuous time horizon and state their price and demand size, and the firm decides whether to accept the request. A semi-Markov decision process is used, and an optimal policy and its analytical properties are found when demand arrives as a semi-Markov process. Past research has found that there is a relation for the pricing elasticity in maximize airlines revenue and yield management.

\section{Literature Review and Operationalize Definition}

The definition of each of terms use in independent variables was explained as below according to previous researchers.

\section{Market Segmentation}

According to Mark Anthony Camilleri (2018), market segmentation defined as: "...... is the actual process of identifying segments of the market and the process of dividing a broad customer base into sub-groups of consumers consisting of existing and prospective customers. Is a consumer- oriented process and can be applied to almost any type of market."

\section{Product Quality}

According to Zeithaml, Bitner, and Gremler, (2009), product quality defined as:".. a consumer's judgment about the overall superiority of a product or service is widely acknowledged as one of the important determinants of brand loyalty."

\section{Demand Forecast}

According to Hoover, Jim (2009), demand forecast defined as: "Demand forecasting is a field of predictive analytics which tries to understand and predict customer demand to optimize supply decisions by corporate supply chain and business management."

\section{Competitive Pricing}

According to Gael Grasset, (2015) pricing competitive defined as: "Competitive pricing consists of setting the price at the same level as one's competitors. This method relies on the idea that competitors have already thoroughly worked on their pricing. In any market, many firms sell the same or very similar products, and according to classical economics, the price for these products should, in theory, already be at an equilibrium (or at least at a local equilibrium)."

However, in this study will narrow focus into specific factor determine the airlines pricing competitive between Full Service Network Carriers (Prime Carriers) and Low Cost Carriers (Budget Airlines) that is operated between KUL to SIN route departure from KLIA or to be specific one way fares level. To define the competitive level, Williams (2018) has looked into 
dynamic airline pricing concept framework in the airline industry, taking into account both forces: intertemporal price discrimination (fares responding to time) and dynamic adjustment to stochastic demand (fares responding to seats sold). The existing research documents the importance of intertemporal price discrimination and dynamic adjustment to stochastic demand separately in airline markets, and the central contribution of this paper is to study them jointly and quantify their interactions. Consistent with the idea of market segmentation, Puller, Sengupta, and Wiggins (2015) find that ticket characteristics, such as advance purchase discount (APD) requirements, explain much of the dispersion in fares. Lazarev (2013) quantifies the welfare effects of airline pricing by estimating a model of intertemporal price discrimination but not dynamic adjustment.

Zentner (2016) has discuss in this case study Service as a Strategy: A Review of Singapore Airlines (SIA). The method for service quality assessment employed by SIA is the use of feedback collection from customers to help gauge employee and operational performance (Hart and Lytle, 1986). Though this information can provide feedback to help leadership understand the climate and perceptions of consumers, it is very limited as feedback is sporadic and may not be fully representative of the target population.

The work Spasojevic (2013) indicated that quality assurance measure have a positive impact on productivity. It would be strongly suggested that SIA triangulates their methods of assessment to include operational benchmarking, with planned surveying to direct populations and the assessment of the external (e.g. economic, cultural) trends to help drive decisions. From Whyte and Lohmann, (2015) case study has define how Jet Star, another key player for low cost carrier between KUL-SIN routing. Several researchers have questioned whether full-service airlines (FSAs) might create distinct business streams on a single integrated production platform. Gillen and Gados (2008) assess the problems associated with mixing business models and suggest that AWAs use different operating parameters requiring a different type of culture that eventually results in a poor strategic fit with the parent airline's business model. Graham and Vowles (2006) post that CWCs represent a strategic response to the growth of low-cost airlines that had tapped into the price-conscious leisure market. Several airlines that previously established subsidiary airlines have now reabsorbed those subsidiaries and created an "economy lite" product that offers a certain number of seats on specific flights "down the back" that require payment for food, refreshments and in-flight entertainment.

Brands are increasingly seen as valuable assets which play an integral part in the marketing strategy (Morling and Strannegard, 2004). Davis (2002) is confident that customers do not have a relationship with a product or service; but they do have relationship with a brand. Brand is suggested to be the purveyor of advantages in economic and symbolic value to the consumer. Previous researchers have developed some theoretical frameworks in identifying consumers' thinking and responses toward brands (De Chernatony et. al, 2011), enabling marketers to obtain sustainable differentiation through effective consumer-centered marketing activities. Aaker (1996) have suggested two paramount developments in branding that focused on brand image. However, Turley and Moore (1995), argued that the branding models proposed were concentrated on product branding instead of services branding. 
Choice between low-cost and full-fare was the topic of few articles before. For example, Mikulić and Prebežac (2011) studied choice between those two types of airlines by surveying passengers of both, and observing which factors were the most important for them. Huse and Evangelho (2007) looked into the same question, but for business travelers, taking into consideration factors usually important for them such as availability of business lounges and frequent-flyer programs. O'Connell and Williams (2005) took into account both leisure and business passengers, looking into which factors were the most important for them while choosing either low cost or full-fare airline. One of interesting findings included "a strong bias towards young people taking low cost carriers" (p. 271). The next factor is service reliability. Safety was found to be extremely important factor in all studies related to choice of any travel product. It is crucial for both leisure and business travelers. The next factor is service reliability. Again, like Mikulić and Prebežac (2011), we are going to include two attributes in this factor:

- Airline safety perceptions

- On-time performance

Safety was found to be extremely important factor in all studies related to choice of any travel product. It is crucial for both leisure and business travelers. Most studies found ontime performance to often be very significant for business travelers on short-haul flights, while passengers taking long-haul flights are usually more time flexible (Proussaloglou and Koppelman, 1999).

Oriol Lordan (2014) also looking into network overview for Full Service Carrier and Low Cost Carrier in his study, Study of the Full-Service and Low-Cost Carriers Network Configuration. All Asian airlines have high values of between ness centrality, showing that they tend to centralize its operations around a set of hubs or bases. Interestingly, LCCs have the lowest values of gamma, while FSCs have higher values. This fact suggests that Asian LCCs plan its route portfolio around a base, which is the origin and destination of most of its routes. Their route network is quite different from the European LCCs, which operate in several bases. It must be noted that Asian LCCs network structure may be limited by the bilateral restrictions; whereas European LCCs network structure may be affected by capacity shortage (consequently) at major airports, etc. Chinese carriers are still subject to entry regulation in domestic markets. Single versus multiple hub network are affected by the size of the network as well as regulatory constraints - domestic or international. According to Loizos Heracleous and Jochen Wirtz (2010), Singapore Airlines is positioned as a premium carrier with high levels of innovation and excellent levels of service, and has made a strategic choice of giving priority to profitability over size. The internal organizational practices outlined in this paper, such as continuous people development and rigorous service design are key aspects of operationalizing and sustaining this positioning and strategic choice. From a case study Willem Smit and Christopher Dula (2014) which is explaining that Scoot as an excellent example of strategic brand positioning: it is well set to shield its parent brand Singapore Airlines from competitive pricing and to help preserve its premium brand status. More than that, however, it allows the group to take advantage of market opportunities that are inaccessible to Singapore Airlines. Scoot is, in fact, a separate airline with a distinct brand, identity and purpose. However, building 
its distinct brand while managing customer expectations as a member of the Singapore Airlines Group was - and will continue to be - a delicate endeavour.

\section{Preposition Development}

Research framework as shows in below Figure 1 with correspondent prepositions. As regards to airfares, passengers will choose any convenience airlines carriers based on the pricing competitive with supportive factors.

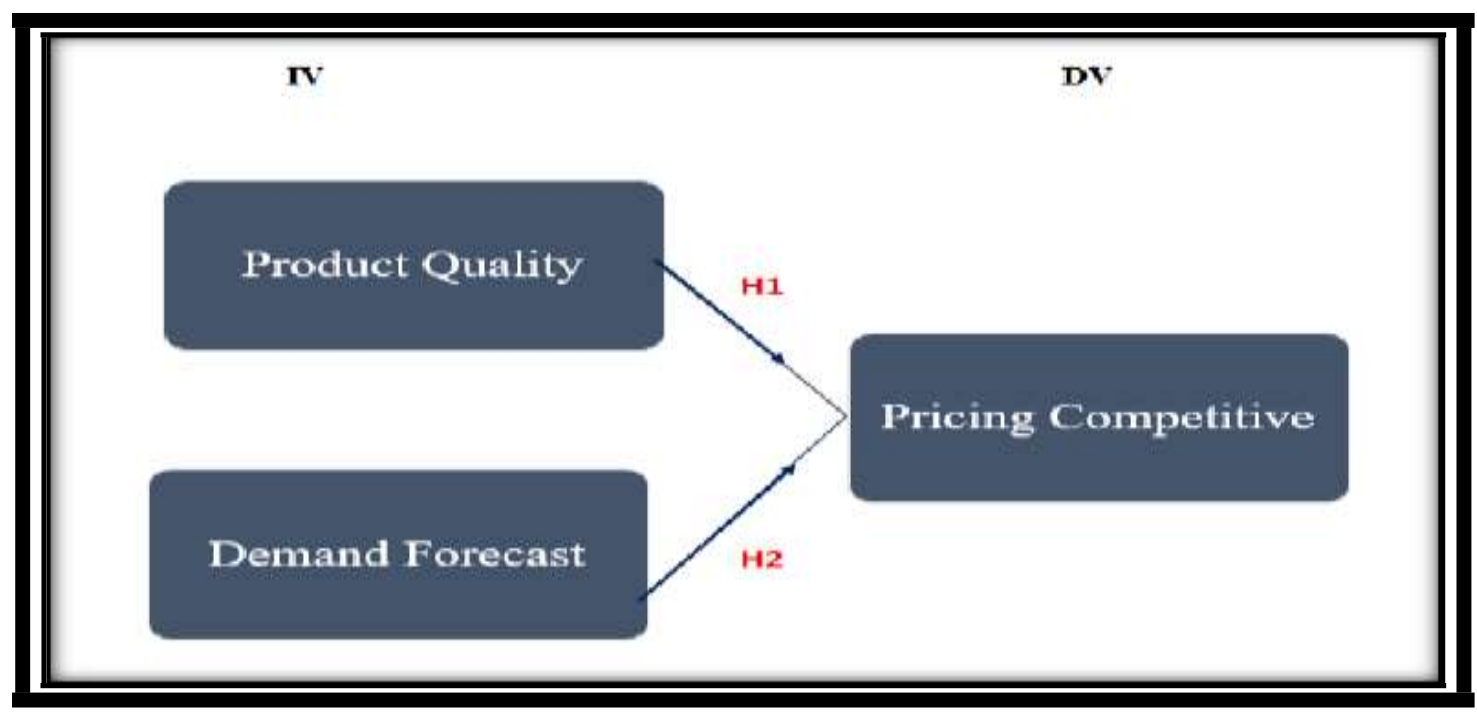

Figure 1 - The Proposed Study Model

The research framework consists an overview of two independent variables, airlines pricing competitive is served as a dependent variable. The independent variables of this study consist of a factor that will affect airlines passenger's intention, airlines passengers' market segmentation, airlines product quality, airlines fares seasonality, seat availability and demand forecast. Besides that, a conceptual framework had been developed in order to examine the relationship between each independent variable and dependent variable. The conceptual framework as shown in Figure 1 was developed to portray the variables that affected the airlines pricing competitive and hence affect the intention to purchase the airfares tickets between prime carriers and budget carriers. In a competitive market one might expect a strong positive relationship between price and product quality. For most products the relationship between price and quality was weak. Hypotheses were developed and tested to explain the variation of price-quality correlations across products. For each airline, there is a study on how to sustain their business by improve the service quality and upgrade the product satisfaction. Some of the low cost carrier or budgets airlines is not provide the same service as prime carrier. This would determine on below prepositions:

Preposition 1: Product Quality significantly influence pricing competitive.

The relations between Demand Forecast and Pricing Competitive.

Since nowadays, Air Asia as a low cost carrier has promote their tagline as "Now, everyone can fly". This is will support that anyone has a chance to use air transportation in order to save their time. This study is concerned in discovering the price consciousness with the demand to purchase of airfares tickets, thus the research hypothesis is proposed as below: Preposition 2: Demand forecast significantly influence the pricing competitive. 


\section{Research and Implications}

These results have important implications for academic and airlines revenue management to further study into details on future recommendations. For an airlines pricing specialist, a greater understanding into the influence of market structure and competition on dynamic pricing provides valuable insights and extends the flow of research details about price elasticity. This research allows collaboration with airlines revenue management department to include more determination factors that analyses details into pricing benchmark and pricing elasticity with dynamics structure. The additional limitation factors that is normally apply internally for a pricing specialist analysis task are details on routes performance, market share between the dominant carrier, fares seasonality, flight frequency schedule and yield management. This factors only be able to proceed with an action research collaboration with an internal airline consultation to improve and maximize revenue of the company. As for limitations this study is limited only on point to point traffic and does not covers the hub and spoke network of flights and looks at only one POS. As such to further research on this study it is highly recommended that an empirical evaluation is to be carried out at the next level as this study is based on literature review on past studies.

\section{Conclusion}

Based on previous and current studies, strategies can be developed to encourage airlines to expand into new markets while discouraging their focus on local markets. The importance of understanding how passengers make decisions is outlined in this paper and detailed insights about the methods involved in the analysis. The countless details of internal and external factors that frequently develop the aviation industry and impact various stakeholders have been explored in this paper and it seems that airlines companies today more than ever have to be very responsive to change. Product quality assortments replicate the analysis of how quickly the competitive advantage can be lost if new opportunities are not reflected or products are not improved and redefined. The need to create an understanding of the passenger's decision- making process becomes evident when analyzing the behavior of passengers who are sensitive to change

Airline policies as regards to network revenue management must approach competitive pricing not only on the types of travelers and other pertinent factors but also at sector length and overall competitive landscape of the route. This is done by concentrating on the factors of product quality and demand forecast whist correlating on the sector length. As this study mainly focusses on international short sector flight length factors on competitive pricing factors. It is thus recommended that future studies to focus on competitive pricing factors at medium to long haul flight sector lengths for the airline industry. 


\section{References}

Aaker. (1996) Building strong brands. The free press.

Anderson, E. W., Fornell, C., Mazvancheryl, S. K. (2004). Customer satisfaction and shareholder value. Journal of Marketing, 68(4), 172-185.

Harker, M., Brennan, R., Kotler, P., Armstrong, G. (2009). Marketing: An Introduction. (3 ed.) Harlow.

Assael, H. (1987). Consumer behavior and marketing action. Kent Publishing, Boston.

Assael, H. (1988).Consumer behavior and marketing Action. Kent Publishing Company, 6th edition, Boston.

Albers, S., Baum, H., Auerbach, S., \& Delfmann, W. (2017). Strategic management in the aviation industry. Routledge.

Bardai, A. M., Er, A. Z., Johari, M. K., \& Noor, A. M. (2017, December). A review of Kuala Lumpur International Airport (KLIA) as a competitive South-East Asia hub. In IOP Conference Series: Materials Science and Engineering (Vol. 270, No. 1, p. 012039). IOP Publishing.

Bauernfeind, U., \& Zins, A. H. (2005). The perception of exploratory browsing and trust with recommender websites. Information Technology \& Tourism, 8(2), 121-136.

Beatty, S. E., \& Smith, S. M. (1987). External search effort: An investigation across several product categories. Journal of consumer research, 14(1), 83-95.

Belobaba, P., Odoni, A., \& Barnhart, C. (Eds.). (2015). The global airline industry. John Wiley \& Sons.

Bieger, T., \& Agosti, S. (2017). Business models in the airline sector-evolution and perspectives. In Strategic management in the aviation industry (pp. 41-64). Routledge.

Böhm, A. (2009). The SWOT Analysis. GRIN Verlag, Munich 63

Moser, G., Pol, E., Bernard, Y., Bonnes, M., Corraliza, J. A., \& Giuliani, V. (Eds.). (2002). People, places, and sustainability. Hogrefe Publishing.

Camilleri, M. A. (2018) The tourism industry: Tourism economics and the airline products Springer international publishing

Chan, D. (2000).The development of the airline industry from 1997-1998: A strategic global overview, Journal of Management Development.

Chen, C. (2006). Identifying significant factors influencing consumer trust in an online travel site. Information Technology, Tourism, Vol. 8, Issue 2 pp 197214

Chen, C. (2008). Investigating structural relationships between service quality, perceived value, satisfaction, and behaviors intentions of air passengers: Evidence from Taiwan. Transportation Research Part A, Vol. 42, pp. 709-717

De Chernatony, L., \& McDonald, M. (1994). Creating Powerful Brands, ButterworthHeinemann.

Crotts, J. (1992). Information search behaviors of free and independent travelers. Visions in Leisure and Business, Vol. 11, Issue 4 
Engel, J. F., Blackwell, R. D., Miniard, P. (1986). Consumer behavior. Drysden Press, 5th edition: Chicago.

Farrell, O. C., Pride, W. M. (2010). Foundations of Marketing. South-Western College/West, 4th edition.

Fodness, D., \& Murray, B. (1997). Tourist information search. Annals of tourism research, 24(3), 503-523.

Gael, G. (2015) Competitive pricing definition.www.lokad.com.

Gerardi, K., Shapiro, A. H. (2007). The effects of competition on price dispersion in the airline industry: A panel analysis. Papers.ssm.com

Gilbert, D., \& Wong, R. K. (2003). Passenger expectations and airline services: a Hong Kong based study. Tourism Management, 24(5), 519-532.

Gillen, D., \& Gados, A. (2008). Airlines within airlines: Assessing the vulnerabilities of mixing business models. Research in Transportation Economics, 24(1), 25-35.

Graham, B., \& Vowles, T. M. (2006). Carriers within carriers: A strategic response to low-cost airline competition. Transport Reviews, 26(1), 105-126.

Guston, B. (1978). Aviation. The Complete Story of Man's Conquest of the Air. Octopus Books: London.

Hanlon, P. (2007). Global Airlines: Competition in a Transnational Industry. ButterworthHeinemann, 3rd edition: Oxford

Hawkins, D., Best, Roger, Coney, Kenneth. (1995). Consumer behavior: Implications for marketing strategy. Irwin Inc. Sixths edition, Chicago

Henderson, J. (2006). Tourism in Dubai: Overcoming Barriers to Destination Development. International Journal of Tourism Research, Volume 8, pp.87-99

Horner, S., Swarbrooke, J. (2007). Consumer Behavior in Tourism.

Hoover, J. (2009)How to track forecast accuracy to guide forecast process improvement.Foresight. Butterworth-Heinemann, 2nd edition, Oxford

Kai, H. Y. (2009). The effect of airline service quality on passengers' behavioural intentions using servqual scores: A Taiwan case study. In Proceedings of the Eastern Asia Society for Transportation Studies (Vol. 2009, pp. 427-427). Eastern Asia Society for Transportation Studies.

Huse, C., \& Evangelho, F. (2007). Investigating business traveller heterogeneity: Low-cost vs fullservice airline users?. Transportation Research Part E: Logistics and Transportation Review, 43(3), 259-268.

Inkpen, G. (1994). Information Technology for Travel and Tourism. Financial Times Prentice Hall, London

Knorr, A., \& Eisenkopf, A. (2007). Emirates Airline-Wachstum ohne Grenzen?.

Lee, K. L., Choy, P. (2004). The reluctant Hong Kong consumer: Purchasing travel online. International Journal of Consumer Studies, Vol. 28, Issue 3, pp 293-304

Kossmann, M. (2006). Delivering excellent service quality in aviation: a practical guide for internal and external service providers. Ashgate Publishing, Ltd..

Kotler, P., Armstrong, G., Wong, V., \& Saunders, J. (2008). Princlipes of marketing. 5th European edition. Harlow. 
Kozak, M., \& Decrop, A. (Eds.). (2009). Handbook of tourist behavior: Theory \& practice. Routledge.

Lovelock, C. H., Wirtz, J., \& Chew, P. (2009). Essentials of services marketing.

Lazayarev, J. (2013)The welfare effects of intertemporal price discrimination. www.lazarev.com

Loizos, H., Wirtz, J. (2014) Singapore airlines balancing act. Harvard business review

Salzer-Mörling, M., \& Strannegård, L. (2004). Silence of the brands. European Journal of Marketing.

Mudie, P., Pirrie, A. (2006). Service Marketing Management. Butterworth-Heinemann,3rd edition, Oxford.

Lordan, O., Sallan, J. M., \& Simo, P. (2014). Study of the topology and robustness of airline route networks from the complex network approach: a survey and research agenda. Journal of Transport Geography, 37, 112-120.

O'Connell, J., Williams, G. (2011). Air Transport in the 21st century:Key Strategic Developments. Ashgate Publishing Limited, Farnham

O' Connell. (2010). Rulers of the silk world. The Economist

O'Connor, P. (1999). Electronic Information Distribution in Tourism and Hospitality. CABI, 1st edition, Oxford

OAG. (2019), Megahubs : 2019 Report. Oag.com, United Kingdom

Oliver, R. L. (1999) Whence consumer loyalty? Sage publications

Pakdil, F., Aydm, O. (2007): Expectations and perceptions in airline service:An nalysis using weighted SERVQUAL scores. Journal of Air Transportation Management, Vol. 13, pp. 229237

Palmer, A. (1994). Principles of Services Marketing. McGraw-Hill Higher Education, 4th Edition: New York Park

Puller, S. L., Sengupta A., Wiggins, S. N. (2009): Testing theories of scarcity pricing in the Airline industry; National Bureau of Economic Research

Robertson, R., Wu, C. L. (2004): The effect on airline service on passengers' behavioral intentions: A Korean case study, Journal of Air Transportation Management, Vol. 10, pp. 435-439

Pizam, A., Mansfeld, Y. (1999). Consumer Behavior in Travel and Tourism. The Haworth Press, Binghamton

Poon, A. (1993). Tourism, Technology and Competitive Strategies. Cab International, Oxford Pride, W. M., Farrell, O. C. (2011). Marketing. South-Western College Pub, 16th edition, Mason.

Proussaloglou, K., \& Koppelman, F. S. (1999). The choice of air carrier, flight, and fare class. Journal of Air Transport Management, 5(4), 193-201.

Rathmell, J. M. (1966). What is meant by services. Journal of Marketing, Vol.30, pp 32-36

Reader, C. (2011). Role of Intermediaries in the Airline Industry. http://www.ehow.com/info_8619928_role-intermediariairlineindustry.html- retrieved on, 1 Nov. 2011

Schiffman, L., Kanuk L. (2006). Consumer Behavior. Englewood Cliffs,9th edition, New Jersey

Schultz, D., Kitchen P. (2000). Communicating Globally: An Integrated Marketing Approach. NTC Business Books. 1st edition, Illinois 
Schultz, D., Schultz, H. (2004). IMC, the next generation: five steps for delivering value and measuring returns using marketing communication. McGraw-Hill Professional, New York

Sheehan, J., Oclott, J. W. (2003). Business and Corporate Aviation Management: On-Demand Air Travel. Mcgraw-Hill Professional,New York

Sismanidou, A., Palacios, M., Tafur, J. (2009). Progress in airline distribution systems: The threat of new entrants to incumbent players. Journal of Industrial Engineering and Management, Vol. 2, number 1,pp 251-272

Spasojevic, V. K. (2013) An empirical examination of the impact of quality tools application on business performance:Evidence from Serbia. Research gate.

Steiner, P., Gabler, V. W. (2011). Sensory Branding: Grundlagen multisensualer Markenführung.

Slyke, R. V., Young, Y. (2000) Finite horizon stochastic knapsacks with approach to yield management. Operations Research.

Taneja, N. (2011). The Passenger Has Gone Digital and Mobile: Accessing and Connecting Through Information and Technology. Ashgate Publishing Limited: Farnham.

Turley, L. W., \& Moore, P. A. (1995). Brand name strategies in the service sector.

O'Connell, J. F., \& Williams, G. (2016). Air transport in the 21st century: key strategic developments. Routledge.

Veal, A. J. (2006). Research Methods for Leisure and Tourism: A Practical Guide. Pearson Education Limited, 3rd edition: Harlow

Wensveen, J. (2007). Air Transportation: A Management Perspective. Ashgate, 6th edition, Hampshire

Werthner, H., Klein, S. (1999). ICT and the Changing Landscape of Global Tourism Distribution.Electronic Markets, Vol. 9, Issue 4,pp 256-262

Werthner, H., Klein, S. (1999). Information technology and tourism:A challenging relationship. Springer, Auflage 1,Wien, pp 42-49

Wheeler, A. (2009). Designing Brand Identity: An Essential Guide for the Whole Branding Team. John Wiley, Sons, 3rd edition: Hoboken

Williams, K. R. (2017) Dynamic airline pricing and seat availability. Cowles foundation for research in economics, Yale University. Paper no.3003

Wilem, S., Dula, C. (2000) Singapore airlines scoots into the low-cost long-haul category Centre for management practice, SMU.

Zeithaml, V., Berry, L., Parasuraman, A. (1996). The behavioral consequences of service quality. Journal of Marketing, Vol. 60, pp 31-52

Zentner , A. (2016) Service as a strategy: A review of Singapore airlines.SSRN

Zoge, M., Buhalis, D. (2008). British Airways: customer enabled interactivity.In,Buhalis, D.,Egger, R., e-tourism case studies. Elsevier Ltd., First Edition:Oxford. pp.269-28. 